\title{
Recovering Whooper Swans do not cause a decline in Eurasian Wigeon via their grazing impact on habitat
}

\section{Pöysä, Hannu}

2018-04

Pöysä , H , Elmberg , J , Gunnarsson , G , Holopainen , S T , Nummi , P J \& Sjöberg , K 2018 , ' Recovering Whooper Swans do not cause a decline in Eurasian Wigeon via their grazing impact on habitat ' , Journal of Ornithology, vol. 159 , no. 2 , pp. 447-455 . https://doi.org/10.1007/s10336-0

http://hdl.handle.net/10138/326304

https://doi.org/10.1007/s10336-017-1520-1

unspecified

acceptedVersion

Downloaded from Helda, University of Helsinki institutional repository.

This is an electronic reprint of the original article.

This reprint may differ from the original in pagination and typographic detail.

Please cite the original version. 
2 Recovering Whooper Swans do not cause decline in Eurasian Wigeon via grazing

3 impact on habitat

4

5

Hannu Pöysä ${ }^{1}$, Johan Elmberg ${ }^{2}$, Gunnar Gunnarsson ${ }^{2}$, Sari Holopainen ${ }^{3}$, Petri Nummi ${ }^{3}$, Kjell Sjöberg ${ }^{4}$

6

7

8

$9 \quad{ }^{1}$ Management and Production of Renewable Resources, Natural Resources Institute Finland, Joensuu,

$10 \quad$ Finland

$11 \quad{ }^{2}$ Division of Natural Sciences, Kristianstad University, Sweden

${ }^{3}$ Department of Forest Sciences, University of Helsinki, Finland

${ }^{4}$ Department of Wildlife, Fish, and Environmental Studies, Swedish University of Agricultural

Sciences, Umeå, Sweden

*Correspondence: Hannu Pöysä, Management and Production of Renewable Resources, Natural

Resources Institute Finland, Yliopistokatu 6, FI-80100 Joensuu, Finland

E-mail: hannu.poysa@luke.fi

Phone: +358400103081

ORCID: 0000-0002-1585-2375

Short title: Recovering whooper swan and declining Eurasian wigeon 


\section{$1 \quad$ Abstract}

2 The Whooper Swan (Cygnus cygnus) is a good example of successful conservation, with rapidly

3 growing numbers in Fennoscandia in recent decades. To the contrary, Eurasian Wigeon (Mareca

4 penelope) shows a strong negative trend in breeding numbers, which raises conservation concerns.

5 Previous research suggests a causal link between recent population trajectories of the two species.

6 Both preferentially breed on wetlands with abundant horsetail (Equisetum spp.), a plant providing

7 food for Whooper Swan and crucial feeding microhabitat for Eurasian Wigeon broods. We here test

8 predictions based on the hypothesis that grazing on Equisetum by Whooper Swan reduces breeding

9 habitat or breeding habitat quality for Eurasian Wigeon. We use data from 60 lakes in which

10 waterfowl were counted in 1990-1991 and 2016, and Equisetum was mapped in 1990-1991 and

11 2013-2014. Lakes colonized by Whooper Swan typically had more abundant Equisetum vegetation in

12 the past than lakes not colonized. Lake-specific decrease of Equisetum was not associated with

13 colonization by Whooper Swan. The number of lakes occupied by Eurasian Wigeon decreased, but

14 the decrease was not stronger on lakes colonized by Whooper Swan than on those that were not.

15 Contrary to our prediction, current Eurasian Wigeon abundance was positively associated with

16 Whooper Swan abundance. Moreover, Eurasian Wigeon did not decrease more on lakes from which

17 Equisetum disappeared than on lakes in which there was still Equisetum left. This study does not support the idea that Whooper Swan affects Eurasian Wigeon negatively by grazing on Equisetum.

Keywords: colonization; grazing pressure; habitat change; lake-level extinction; species interaction; waterbird community 
1

2 Habitat change and interspecific interactions modify species assemblages by affecting population

\section{Introduction} sizes of individual species. Opposite population changes, although not necessarily causally linked, may indicate competitive interactions (MacNally et al. 2012) or other processes mediated for example by habitat change affecting species differently (Ewers and Didham 2006; Öckinger et al. 2010). Negative interaction between two species may arise also from processes in which one of the species alters the habitat preferred by the other species in a way that is disadvantageous to the latter (i.e. amensalism). Cascading effects of herbivory by large ungulates in African savannas and elsewhere provide examples of such indirect and often complex interactions (Pringle et al. 2007; Foster et al. 2014). An avian example of overgrazing and habitat degradation effects is provided by the strongly increased Lesser Snow Goose (Chen caerulescens caerulescens) on their Arctic and subarctic breeding grounds (Peterson et al. 2013, 2014). Specifically, grazing by Lesser Snow Goose has led to a dramatic reduction in preferred shrub habitat for nesting Savannah Sparrows (Passerculus sandwichensis), contributing to the long-term decline in nesting occurrence of the species in the La Pérouse Bay area, Canada (Peterson et al. 2014).

Boreal waterbird communities are undergoing changes in species relative abundances as population declines or increases have been documented for several species (Lehikoinen et al. 2013, 2016; Pöysä et al. 2013). One potential example of negative interaction between species in these communities is Eurasian Wigeon (Mareca penelope) and Whooper Swan (Cygnus cygnus), the breeding numbers of the former showing an alarming negative trend and those of the latter a dramatic increase (Ottosson et al. 2012; Lehikoinen et al. 2013, 2016). Breeding Eurasian Wigeon prefer lakes with abundant Water Horsetail Equisetum fluviatile (Pöysä et al. 2017) (hereafter, Equisetum). Eurasian Wigeon does not feed on Equisetum but emergent stands of this aquatic plant provide important foraging microhabitat for breeding adults and broods (Jacobsen 1993; Nummi et al. 2013). By contrast, Whooper Swan feeds on Equisetum (Haapanen et al. 1977; Knudsen et al. 2002). Haapanen et al. (1977) found that in the middle of summer (July) Whooper Swans spent about 50\% of the total feeding time on eating Equisetum shoots. The authors also report on an example in which 
Whooper Swans spent about $70 \%$ of total time (from incubation until the cygnets were 10 weeks old) in the part of the breeding lake that had extensive Equisetum stands. Whooper Swan grazing may also cause severe local damage to stands of this plant (see Pöysä et al. 2017). Presence and abundance of Equisetum have declined dramatically in boreal lakes in Finland and Sweden during the last two decades, a fact that has been suggested to contribute to population decline in Eurasian Wigeon (Pöysä et al. 2017). One of the hypotheses put forward by Pöysä et al. (2017) to explain Equisetum decline is grazing by Whooper Swan. Indeed, it has been found in several studies that swans in general can cause strong habitat modifications by reducing aquatic plant cover and standing crop (Sandsten and Klaassen 2008; Gayet et al. 2011a; Wood et al. 2012), and therefore have been recognized as species that potentially affect the structure and functioning of aquatic communities and ecosystems (Bakker et al. 2016a, b; Wood et al. 2017).

Pöysä et al. (2017) called for further research to resolve whether the decrease of Equisetum habitat directly links to the decrease of Eurasian Wigeon numbers and to address possible causal links between increased numbers of herbivores such as the Whooper Swan, decreased Equisetum abundance and Eurasian Wigeon numbers. Pinpointing possible causal relationships between the documented changes is fundamental to proper conservation and management of these species and their habitats. The matter is urgent, as the conservation status of Eurasian Wigeon is now "Vulnerable" in one of the breeding strongholds, Finland (Tiainen et al. 2016), and also in Europe at the EU27 level (BirdLife International 2015).

Moreover, we probably have a conservation paradox at hand. The Whooper Swan is a spectacular and inspiring example of successful conservation efforts, as the species was close to extinction in Finland and Sweden in the early 1900s, but protection from hunting have helped it to recover surprisingly rapidly (Haapanen 1987, 1991; Ottosson et al. 2012; Lehikoinen et al. 2013). For example, in the mid 1940s in Finland, the species bred only in northernmost Lapland and near the border to Russia, with only 15 estimated pairs in the entire country (Merikallio 1958). The current population estimate for Finland is 17 000-22 000 individuals (Tiainen et al. 2016). The dramatic increase of the Whooper Swan has created a lot of speculation and societal discussion about its 
possible negative effects on populations of other waterbird species, but no such effects have so far been documented (Pöysä and Sorjonen 2000). Hence, the recent recovery of the Whooper Swan has brought about unexpected conservation, management and societal challenges that need to be addressed, and a complex set of problems has recently been recognized with some other strongly increasing native species (Carey et al. 2012; Roman et al. 2015). Based on these concerns, and on findings in our earlier study (Pöysä et al. 2017), we formulated a set of predictions to address the hypothesis that the decrease of Eurasian Wigeon and increase of Whooper Swan are causally linked via decline in Equisetum abundance: 1) Lakes colonized by Whooper Swan typically have had abundant Equisetum vegetation in the past; 2) Equisetum has decreased more on lakes colonized by Whooper Swan than on lakes not colonized; 3) Eurasian Wigeon has decreased more on lakes that have been colonized by Whooper Swan than on lakes that have not been colonized; and, as a consequence, current breeding lake occupation of Eurasian Wigeon should be negatively associated with that of Whooper Swan; 4) Eurasian Wigeon has decreased most on lakes where Equisetum has decreased most. With its lake-level approach, our study aims to find a direct link between large-scale population changes and processes occurring at local (population) level, a link that is often lacking in studies on species' declines (Scheele et al. 2017).

\section{Materials and methods}

\section{Eurasian Wigeon, Whooper Swan and Equisetum data}

To test our predictions we repeated waterfowl surveys and vegetation mapping of lakes carried out in an earlier study (Elmberg et al. 1993). For that study, ten lakes were selected in each of six study regions (i.e. in all 60 lakes) between $56^{\circ}$ and $67^{\circ} \mathrm{N}$ in Finland and Sweden (Table 1) to represent the local gradient from eutrophic to oligotrophic conditions as indicated by the luxuriance of aquatic vegetation (see Table 2 in Elmberg et al. 1993). On each of the 60 lakes, waterfowl were counted and vegetation mapped in 1990-1991 according to the field methods described in Elmberg et al. (1993). In brief, two waterfowl surveys were done in April and May using the waterfowl point count method of Koskimies and Väisänen (1991); the timing of waterfowl surveys was adjusted to take into account 
differences in spring phenology between the regions. Vegetation mapping was done in July in 19901991. The structure of emergent vegetation along the shores of each lake was described using six vegetation types (see Elmberg et al. 1993 for details). As we are here specifically interested in Equisetum, we calculated the total length of Equisetum-dominated shoreline for each of the 60 lakes (see Pöysä et al. 2017).

We repeated waterfowl surveys in 2016 and the mapping of Equisetum vegetation in 2013-2014 on the same lakes using the same field protocol as in Elmberg et al. (1993), with the following exceptions. Waterfowl point counts were done only once in 2016 in region 1 (see Fig. 1 in Elmberg et al. 1993); the date of this single count was approximately between the dates of the two counts in 1990-1991. In addition, one lake from region 1 was excluded due to increased human settlement. For the same reason the mapping of Equisetum was not repeated in 2013-2014 on that lake and on another lake in the same region (see Pöysä et al. 2017); these two lakes were excluded from all analyses dealing with change in Equisetum abundance.

Data on lake occupation by Eurasian Wigeon and Whooper Swan pairs in 1990-1991 and in 2016 were derived from the corresponding duck surveys described above. For the present study, we used presence/absence data as well as the lake-specific pair number of Eurasian Wigeon and Whooper Swan. A lake was classified as occupied by Eurasian Wigeon or Whooper Swan if at least one breeding pair of the species was observed in either of the two surveys (or in the single survey in 2016 for lakes from region 1, see above). We calculated average pair numbers from the two surveys, except for the lakes from region 1 in 2016, for which we used the pair numbers from the single census. The total length of Equisetum shoreline habitat was measured at each lake in 2013-2014 in the same way as in 1990-1991 described in Elmberg et al. (1993); in principle, we used the same Equisetum data as in Pöysä et al. (2017, Fig. 2).

In total we studied 60 lakes, but the number included in a specific analysis depended on the study question. For example, when analyzing the association between Eurasian Wigeon and Whooper Swan, lakes from region 6 (i.e. the southernmost region, Table 1) were excluded, because the general breeding distribution of these species does not extend to southernmost Sweden (i.e. they have a 
northern distribution, Ottosson et al. 2012). Criteria for the inclusion of lakes in a given analysis are specified in Results.

\section{Statistical methods}

Because most data did not meet requirements of parametric tests, we used non-parametric tests throughout. Changes between 1990-1991 and 2016 in the number of lakes occupied by Eurasian

Wigeon and Whooper Swan were tested with sign test. We used Mann-Whitney $U$-test for comparison of differences between groups (i.e. tests for data summarized in Tables 2-5). We used both absolute and percentage change of a given response variable in the comparisons. This was because, for example, a decrease of say $90 \mathrm{~m}$ in Equisetum obviously has a large effect in a lake with $100 \mathrm{~m}$ of Equisetum in total, whereas a $90 \mathrm{~m}$ decrease in a lake with $1000 \mathrm{~m}$ of Equisetum would probably be of minor importance. On the other hand, pure percentage decrease may not be informative if two lakes initially have very different amounts of Equisetum; in other words, a 90\% decrease in Equisetum may be highly influential on a lake that has had $1000 \mathrm{~m}$ of Equisetum, whereas 90\% decrease would not matter so much if the lake had only $10 \mathrm{~m}$ of Equisetum. We used logistic regression to test whether the disappearance of Equisetum ( 0 = not disappeared, 1 = disappeared) was associated with lake colonization $(0=$ not colonized, $1=$ colonized $)$ by Whooper Swan and to test for association in lake occupation $(0=$ not occupied, $1=$ occupied $)$ by Eurasian Wigeon and Whooper Swan. Finally, we used Spearman rank correlation to test if percentage change in Eurasian Wigeon pair number was associated with percentage change in the abundance of Equisetum.

\section{Results}

\section{Whooper Swan and Equisetum}

The number of lakes occupied by Whooper Swan increased from 3 to 16 (Sign test, $p<0.001$ ) between 1990-1991 and 2016; the three lakes that were occupied by Whooper Swan already in 1990- 
1991 did have this species also in 2016. Lakes colonized by Whooper Swan typically had more abundant Equisetum vegetation in the past than lakes not colonized (Table 2).

As documented in Pöysä et al. (2017), Equisetum decreased considerably from 1990-1991 to 2013-2014 in most of the lakes studied here. However, lake-specific decrease of Equisetum was not associated with colonization by Whooper Swan (Table 3). Many lakes lost Equisetum altogether but that phenomenon was not associated with lake colonization by Whooper Swan either (logistic regression, $\beta=-1.281, \mathrm{SE}=0.837, Z=-1.531, p=0.126, n=27$ lakes in which Equisetum occurred either in 1990-1991 or in 2013-2014; lakes that were occupied by Whooper Swan already in 19901991 were excluded); in particular, there were 12 lakes from which Equisetum disappeared from the early to the late time period even though they were not colonized by Whooper Swan during that time. Finally, nor was the disappearance of Equisetum associated with presence of Whooper Swan either in 1990-1991 or in 2016 (logistic regression, $\beta=-1.212, \mathrm{SE}=0.791, Z=-1.532, p=0.126, n=29$ lakes that were occupied by Whooper Swan already in 1990-1991 or were colonized after that).

\section{Eurasian Wigeon, Whooper Swan and Equisetum}

The number of lakes occupied by Eurasian Wigeon decreased from 18 to 9 (Sign test, $p=0.035$ ) between 1990-1991 and 2016. The decrease was not more severe on lakes that were colonized by Whooper Swan than on those not colonized (Table 4). Nor was current lake occupation of Eurasian Wigeon negatively associated with that of Whooper Swan; in fact the association was positive (logistic regression, $\beta=1.825, \mathrm{SE}=0.795, Z=2.295, p=0.022, n=50$ lakes from the five regions in which both species occurred in 2016). Finally, Eurasian Wigeon did not decrease more on lakes from which Equisetum disappeared after 1990-1991 than on lakes in which there was still Equisetum left in 2013-2014 (Table 5). Similarly, there was no correlation between the proportional (\%) change of Eurasian Wigeon pair number and the proportional (\%) change in the length of Equisetum-dominated shoreline (Spearman rank correlation, $r_{s}=-0.211, p>0.30, n=15$ lakes in which both Eurasian Wigeon and Equisetum were observed either in 1990-1991 or in 2013-2014/2016). 


\section{Discussion}

3 The number of lakes occupied by Whooper Swan in our study regions increased from 1990-1991 to

4 2016, whereas the number of lakes occupied by Eurasian Wigeon decreased over the same period.

5 However, we did not find support for the idea that these opposite trends are causally linked at the lake

6 level. The lake-specific decrease of Eurasian Wigeon was not associated with Whooper Swan

7 colonization, nor was current lake occupation by Eurasian Wigeon negatively associated with

8 presence of Whooper Swan. Furthermore, while Equisetum has decreased concurrently with

9 increasing Whooper Swan, the colonization of lakes by Whooper Swan alone does not explain

Equisetum decrease; there were several cases in which Equisetum had disappeared from a lake

although it had not been colonized by Whooper Swan. Finally, we found that the lake-specific decrease of Eurasian Wigeon was not associated with the disappearance of Equisetum from the lake; we note, however, that sample size here was relatively small and, therefore, the power of our test low in this particular case.

The increase in lake occupation by Whooper Swan and the corresponding decrease in Eurasian Wigeon in our study are in line with overall population changes of these species in Finland and Sweden (Valkama et al. 2011; Ottosson et al. 2012; Lehikoinen et al. 2013). That we did not find evidence for a negative lake-level impact of the Whooper Swan on Eurasian Wigeon breeding numbers and lake occupation is in line with Pöysä and Sorjonen (2000), who similarly studied changes in breeding numbers of Eurasian Wigeon and other dabbling duck species in lakes that had been colonized by Whooper Swan versus control lakes that had not been colonized. Our present results add new information about the relationship between these two species as we studied the possibility of a habitat change-mediated effect of Whooper Swan, a link that was not even recognized at the time when the data for Pöysä and Sorjonen (2000) were collected (between 1985 and 1997). Even so, our present results suggest that the lake-level decrease of Eurasian Wigeon is not due to a presumed Whooper Swan-caused decrease in Equisetum abundance (but see below for the interaction between Whooper Swan and Equisetum). 
Our results have more general implications when it comes to the presumed impact of large and increasing herbivorous birds such as swans on other waterfowl species (Conover and Kania 1994; Pöysä and Sorjonen 2000; Gayet et al. 2014, 2016; Wood et al. 2017), and whether these species thus could be considered 'invasive' sensu Valéry et al. (2008, 2009), i.e. irrespective of whether they are native or not (see also Carey et al. 2012; Gayet et al. 2014). Specifically, it has been proposed that increasing swan populations in general have negative impact on abundance of other waterfowl species. Neither the current study nor Pöysä and Sorjonen (2000) found such an impact. Similarly, Gayet et al. (2011b) did not find any negative impact of Mute Swan (Cygnus olor) pair presence on the occurrence of other waterbirds on fishponds in eastern France. Gayet et al. (2014) also concluded that Mute Swan population increase cannot be considered as a biological invasion in Europe. Nor did Wood et al. (2017) find support for the idea that swans in general are more aggressive than other groups of waterbirds. Based on our current findings and those of Pöysä and Sorjonen (2000) we suggest that colonization of eutrophic lakes by Whooper Swan has not contributed to the overall decline of waterbird species on those lakes (Pöysä et al. 2013; Lehikoinen et al. 2016). Hence, current knowledge does not support the idea that Whooper Swan has become invasive sensu Valéry et al. (2008, 2009) within boreal waterfowl communities.

Contrary to our prediction, lake-level decrease of Eurasian Wigeon was not associated with lakelevel decrease of Equisetum. This is somewhat surprising; based on previous findings that breeding Eurasian Wigeon prefer lakes with abundant Equisetum vegetation (Pöysä et al. 2017), lakes that have lost Equisetum should have become less suitable and less occupied, and, as consequence, should have shown stronger decrease in breeding Eurasian Wigeon numbers. For comparison, Lehikoinen et al. (2016) documented that the population decline of Eurasian Wigeon since the early 1990s has been stronger on eutrophic (preferred habitat) than on oligotrophic wetlands (less preferred habitat). If habitat selection is density-dependent and follows predictions of the ideal free distribution theory, preferred habitats should always be occupied and less preferred habitats should lose breeding individuals first when overall population density decreases (Fretwell and Lucas 1970; O'Connor 1986). Hence, assuming that habitat distribution is at equilibrium and density-dependent, one would 
expect equal decreases in Eurasian Wigeon numbers only if the rate of habitat deterioration was equal irrespective of the change in Equisetum abundance. On the other hand, it is possible that due to the long-term population decline, breeding numbers of Eurasian Wigeon are far below present carrying capacity; at low population densities habitat occupation may be largely driven by stochastic events (Wiens and Rotenberry 1981; Beletsky and Orians 1994; Haila et al. 1996). There were five lakes in our sample that did not have Equisetum at all (i.e. neither in 1990-1991 nor in 2013-2014) but did have Eurasian Wigeon, which decreased on three of these lakes but increased on the two other. These observations suggest that stochastic events may indeed affect lake occupation of Eurasian Wigeon at current densities, the overall lake-level trend being a decline irrespective of habitat type and quality. Also factors other than those related to Equisetum foraging habitat obviously affect lake selection of Eurasian Wigeon pairs (e.g. nest predation risk), and the presence of Equisetum alone is not a sufficient measure of habitat quality. For example, well developed sedge (Carex spp.) stands may provide alternative foraging habitat for Eurasian Wigeon (Jacobsen 1991, 1993). Indeed, ideally habitat quality should be measured in terms of demography (van Horne 1983; Johnson 2007). Finally, site tenacity of breeding individuals and time lags in response to habitat change (O’Connor 1985; Wiens et al. 1986; Beletsky and Orians 1994; see also Pöysä 2001) may also explain why lakes with decreased Equisetum abundance were occupied by breeding Eurasian Wigeon, although such effects should not last over such long periods as in the present study. Also important to note here is that we only considered associations between Equisetum and the occupancy of breeding pairs. That we did not find any such correlation is not to say this also goes for other phases of the breeding period, in particual the brood-rearing period, which in fact may be more important than the "pair phase" in demographic terms. All in all, factors affecting habitat occupation, habitat-specific breeding success and habitat-specific changes in breeding numbers of Eurasian Wigeon warrant further research, in particular because we still do not know all the reasons underlying the long-term population decline of the species.

Our study sheds new light on possible reasons for the Equisetum decline in that grazing pressure by Whooper Swan alone cannot explain it. We note, however, that as our direct observations from the 
field indicate (see Pöysä et al. 2017), grazing by Whooper Swan affects Equisetum stands negatively. We should keep in mind that herbivore impact on macrophytes depends on consumer density, especially the biomass density of consumers (Wood et al. 2012, 2017). Because of strong territoriality, breeding density of Whooper Swan in boreal lakes is low, usually only one pair or family per lake (see below). Hence whole-lake grazing pressure is probably often relatively low, although recurrent grazing over several years may be influential also at lake level, especially in small lakes. We suggest that grazing by Whooper Swan is only one among possibly several reasons behind the decline of Equisetum. As is discussed in Pöysä et al. (2017), other herbivores could come into question and several possible anthropogenic stressors may affect Equisetum abundance. A decline of Equisetum has been observed in many other lakes than those studied by us. For example, Nurminen (2003) found it in lake Hiidenvesi, a strongly eutrophicated lake in southwestern Finland. She speculated that changes in bottom structure in the lake had been disadvantageous to Equisetum; specifically, a softening of the bottom substrate combined with water level fluctuations and ice erosion may have contributed to the decline. One aspect that merits further investigation is what kind of role drastically increased cyprinid fish populations (Olin et al. 2002) may have in this kind of process; due to their foraging habits cyprinids may directly impact soft bottom sediments of eutrophicated lakes and cause bioturbation (Hansson et al. 1998). In sum, exclosure experiments are needed to confirm our current findings related to grazing by Whooper Swan, and to disentangle such effects on Equisetum from other factors such as impacts of cyprinids.

Our data are snapshots from two time periods c. 25 years apart and this may bring about problems in the interpretation, especially related to Eurasian Wigeon and Whooper Swan data. However, we consider the observed changes real as they are in line with other studies based on longterm data from Finland and Sweden for both species (Ottosson et al. 2012; Lehikoinen et al. 2013, 2016). Furthermore, the impact of Whooper Swan on Equisetum could be confounded if Whooper Swans do not breed consistently on a given lake but frequently switch lakes between years and, in particular, abandon a lake after the disappearance of Equisetum. We do not think this is the case, however, since Whooper Swan is a long-lived species with high breeding site fidelity (Saurola et al. 
2013). For example, in one of the current study lakes (lake Kivilahti) from region 4 (southeastern Finland; see Elmberg et al. 1993, Fig. 1), where waterfowl numbers have been surveyed annually since 1985 (Pöysä and Pesonen 2003), Whooper Swan colonized the lake in 1995 and one pair has been observed on it every year until 2016 (H Pöysä, unpubl. data). Another lake (Humallampi) from the same region was colonized by Whooper Swan in 1999 and that lake, too, has been occupied by one pair of Whooper Swan since then every year until 2016. In the first-mentioned lake, Equisetum declined in extent from $1874 \mathrm{~m}$ to $405 \mathrm{~m}$ between 1990 and 2014, whereas in the latter lake, Equisetum had disappeared by 2013 (extent of Equisetum-dominated shoreline was $981 \mathrm{~m}$ in 1990). On both of these lakes, vigorous fights between Whooper Swan pairs have been observed (H Pöysä, unpubl.), so we cannot be sure if the same pairs have occupied the lakes throughout the years.

Nevertheless, these observations suggest that, once a lake has been selected by a Whooper Swan pair, lake occupation is regular and continues even after Equisetum decline or disappearance.

In conclusion, we did not find support for the idea that the decline of Eurasian Wigeon breeding numbers is causally related to the increase of Whooper Swan. Whooper Swan may eradicate Equisetum stands locally, a foraging habitat preferred by Eurasian Wigeon broods, but grazing pressure by Whooper Swan alone does not explain the drastic decrease of this vegetation type in boreal lakes. Further research is needed about factors affecting habitat occupation, habitat-specific breeding success and habitat-specific changes in breeding numbers of Eurasian Wigeon, as we do not know the reasons underlying the long-term population decline of the species.

\section{Acknowledgements}

This study was supported by previous grants from the Swedish Environmental Protection Agency. We would like to thank Suomalais-ruotsalainen kulttuurirahasto (Finnish-Swedish Cultural Foundation) for supporting a workshop in Sweden to work on this manuscript. A grant by Maj and Tor Nessling Foundation to SH is highly appreciated. A grant from Letterstedtska Föreningen (67/16) facilitated 
JE's participation in the project. We thank two anonymous reviewers for useful comments on the manuscript.

\section{References}

Bakker ES, Pagès JF, Arthur R, Alcoverro T (2016a) Assessing the role of large herbivores in the structuring and functioning of freshwater and marine angiosperm ecosystems. Ecography $39: 162-179$

\section{Bakker ES, Wood KA, Pagès JF, Veend GF, Christianen MJA, Santamaría L, Nolet BA, Hilt S} (2016b) Herbivory on freshwater and marine macrophytes: a review and perspective. Aquat Bot $135: 18-36$

Beletsky LD, Orians GH (1994) Site fidelity and territorial movements of males in a rapidly declining population of yellow-headed blackbirds. Behav Ecol Sociobiol 34:257-265

BirdLife International (2015) European Red List of Birds. Office for Official Publications of the European Communities, Luxembourg

Carey MP, Sanderson BL, Barnas KA, Olden JD (2012) Native invaders - challenges for science, management, policy, and society. Front Ecol Environ 10:373-381

Conover MR, Kania GS (1994) Impact of interspecific aggression and herbivory by mute swans on native water-fowl and aquatic vegetation in New England. Auk 111:744-748

Elmberg J, Nummi P, Pöysä H, Sjöberg K (1993) Factors affecting species number and density of dabbling duck guilds in North Europe. Ecography 16:251-260

Ewers RM, Didham RK (2006) Confounding factors in the detection of species responses to habitat fragmentation. Biol Rev 81:117-142

Foster CN, Barton PS, Lindenmayer DB (2014) Effects of large native herbivores on other animals. J Appl Ecol 51:929-938

Fox AD, Dalby L, Christensen TK, Nagy S, Balsby TJS, Crowe O, Clausen P, Deceuninck B, Devos K, Holt CA, Hornman M, Keller V, Langendoen T, Lehikoinen A, Lorentsen S-H, Molina B, 
Nilsson L, Stipniece A, Svenning J-C, Wahl J (2016) Seeking explanations for recent changes in abundance of wintering Eurasian Wigeon (Anas penelope) in northwest Europe. Ornis Fenn 93:12-25

Fretwell SD, Lucas HJ, Jr (1970) On territorial behaviour and other factors influencing habitat distribution in birds. I. Theoretical development. Acta Biotheor 19:16-36

Gayet G, Guillemain M, Fritz H, Mesleard F, Begnis C, Costiou A, Body G, Curtet L, Broyer J (2011a) Do mute swan (Cygnus olor) grazing, swan residence and fishpond nutrient availability interactively control macrophyte communities? Aquat Bot 95:110-116

Gayet G, Guillemain M, Mesléard F, Fritz H, Vaux V, Broyer J (2011b) Are Mute Swans (Cygnus olor) really limiting fishpond use by waterbirds in the Dombes, Eastern France. J Ornithol $152: 45-53$

Gayet G, Guillemain M, Defos du Rau P, Grillas P (2014) Effects of mute swan on wetlands: a synthesis. Hydrobiologia 723:195-204

Gayet G, Calenge C, Broyer J, Mesléard F, Vaux V, Fritz H, Guillemain M (2016) Analysis of spatial point pattern shows no desertion of breeding mute swan areas by the other waterbirds within fishpond. Acta Ornithol 51:151-162

Haapanen A (1987) The whooper swan population in Finland. Lintumies 22:146-150, in Finnish with English summary

Haapanen A (1991) Whooper swan Cygnus c. cygnus population dynamics in Finland. Wildfowl Suppl 1:137-141

Haapanen A, Helminen M, Suomalainen HK (1977) The summer behaviour and habitat use of the whooper swan, Cygnus c. cygnus. Finnish Game Res 36:49-81

Haila Y, Nicholls AO, Hanski IK, Raivio S (1996) Stochasticity in bird habitat selection: year-to-year changes in territory locations in a boreal forest bird assemblage. Oikos 76:536-552

Hansson L-A, Annadotter H, Bergman E, Hamrin SF, Jeppesen E, Kairesalo T, Luokkanen E, Nilsson P-Å, Søndergaard M, Strand J (1998) Biomanipulation as an application of food-chain theory: constraints, synthesis, and recommendations for temperate lakes. Ecosystems 1:558-574 
Jacobsen OW, (1991) Feeding behavior of breeding wigeon Anas penelope in relation to seasonal emergence and swarming behavior of chironomids. Ardea 79:309-418

Jacobsen OW (1993) Use of feeding habitats by breeding Eurasian wigeon. Can J Zool 71:1046-1054

Johnson MD (2007) Measuring habitat quality: a review. Condor 109:489-504

Knudsen HL, Laubek B, Ohtonen A (2002) Growth and survival of whooper swan cygnets reared in different habitats in Finland. Waterbirds 25:211-220

Lehikoinen A, Pöysä H, Rintala J, Väisänen RA (2013) Population changes of 20 waterbird species in Finnish lakes in 1986-2012. Linnut-Vuosikirja 2012:95-101, in Finnish with English summary

Lehikoinen A, Rintala J, Lammi E, Pöysä H (2016) Habitat-specific population trajectories in boreal waterbirds: alarming trends and bioindicators for wetlands. Anim Conserv 19:88-95

Mac Nally R, Bowen M, Howes A, McAlpine CA, Maron M (2012) Despotic, high-impact species and the subcontinental scale control of avian assemblage structure. Ecology 93:668-678

Merikallio E (1958) Finnish birds. Their distribution and numbers. Fauna Fenn 5:1-181

Nummi P, Paasivaara A, Suhonen S, Pöysä H (2013) Wetland use by brood-rearing female ducks in a boreal forest landscape: the importance of food and habitat. Ibis 155:68-79

Öckinger E, Schweiger O, Crist TO, Debinski DM, Krauss J, Kuussaari M, Petersen JD, Pöyry J, Settele J, Summerville KS, Bommarco R (2010) Life-history traits predict species responses to habitat area and isolation: a cross-continental synthesis. Ecol Lett 13:969-979

O'Connor RJ (1985) Behavioural regulation of bird populations: a review of habitat use in relation to migration and residency. In: Smith RH, Sibly RM (eds) Behavioural ecology: ecological consequences of adaptive behaviour. Blackwell Scientific, Oxford, pp 105-142

O’Connor RJ (1986) Dynamical aspects of avian habitat use. In: Verner J, Morrison ML, Ralph CJ (eds) Wildlife 2000. Modeling habitat relationships of terrestrial vertebrates. The University of Wisconsin Press, Madison, pp 235-240.

Olin M, Rask M, Ruuhijärvi J, Kurkilahti M, Ala-Opas P, Ylönen O (2002) Fish community structure in mesotrophic and eutrophic lakes of southern Finland: the relative abundances of percids and cyprinids along a trophic gradient. J Fish Biol 60:593-612 
1 Ottosson U, Ottvall R, Elmberg J, Green M, Gustafsson R, Haas F, Holmqvist N, Lindström Å,

2 Nilsson L, Svensson M, Tjernberg M (2012) Fåglarna i Sverige - antal och förekomst. Sveriges Ornitologiska Förening, Stockholm, in Swedish with English summary

Peterson SL, Rockwell RF, Witte CR, Koons DN (2013) The legacy of destructive Snow Goose foraging on supratidal marsh habitat in the Hudson Bay Lowlands. Arctic Antarctic Alpine Res $45: 575-583$

Peterson SL, Rockwell RF, Witte CR, Koons DN (2014) Legacy effects of habitat degradation by Lesser Snow Geese on nesting Savannah Sparrows. Condor 116:527-537

Pöysä H (2001) Dynamics of habitat distribution in breeding mallards: assessing the applicability of current habitat selection models. Oikos 94:365-373

Pöysä H, Pesonen M (2003) Density dependence, regulation and open-closed populations: insights from the wigeon, Anas penelope. Oikos 102:358-366

Pöysä H, Sorjonen J (2000) Recolonization of breeding waterfowl communities by the whooper swan: vacant niches available. Ecography 23:342-348

Pöysä H, Elmberg J, Gunnarsson G, Holopainen S, Nummi P, Sjöberg K (2017) Habitat associations and habitat change: seeking explanation for population decline in breeding Eurasian wigeon Anas penelope. Hydrobiologia 785:207-217

Pöysä H, Rintala J, Lehikoinen A, Väisänen RA (2013) The importance of hunting pressure, habitat preference and life history for population trends of breeding waterbirds in Finland. Eur J Wildl Res 59:245-256

Pringle RM, Young TP, Rubenstein DI, McCauley DJ (2007) Herbivore-initiated interaction cascades and their modulation by productivity in an African savanna. Proc. Natl. Acad. Sci. USA 104:193197

Roman J, Dunphy-Daly MM, Johnston DW, Read AJ (2015) Lifting baselines to address the consequences of conservation success. Trends Ecol Evol 30:299-302

Sandsten H, Klaassen M (2008) Swan foraging shapes spatial distribution of two submerged plants, favouring the preferred prey species. Oecologia 156:569-576 
Saurola P, Valkama J, Velmala W (2013) The Finnish Bird Ringing Atlas. Vol 1. Finnish Museum of Natural History and Ministry of Environment, Helsinki

Scheele BC, Foster CN, Banks SC, Lindenmayer DB (2017) Niche contractions in declining species: mechanisms and consequences. Trends Ecol Evol 32:346-355

Tiainen J, Mikkola-Roos M, Below A, Jukarainen A, Lehikoinen A, Lehtiniemi T, Pessa J, Rajasärkkä A, Rintala J, Sirkiä P, Valkama J (2016) The 2015 Red List of Finnish Bird Species. Ympäristöministeriö \& Suomen ympäristökeskus, Helsinki

Valéry L, Fritz H, Lefeuvre JC, Simberloff D (2008) In search of a real definition of the biological invasion phenomenon itself. Biol Invasions 10:1345-1351

Valéry, L., Fritz, H., Lefeuvre, J., \& Simberloff, D. (2009). Invasive species can also be native. Trends Ecol. Evol. 24, 585.

Valkama J, Vepsälänen V, Lehikoinen A (2011) The Third Finnish Breeding Bird Atlas. Finnish Museum of Natural History and Ministry of Environment, Helsinki, http://atlas3.lintuatlas.fi/english. Accessed 20 June, 2017.

van Horne B (1983) Density as a misleading indicator of habitat quality. J Wildl Manage 47:893-901

Wiens JA, Rotenberry JT (1981) Habitat associations and community structure of birds in shrubsteppe environments. Ecol Monogr 51:21-42

Wiens JA, Rotenberry JT, van Horne B (1986) A lesson in the limitations of field experiments: shrubsteppe birds and habitat alteration. Ecology 67:365-376

Wood KA, O’Hare MT, McDonald C, Searle KR, Daunt F, Stillman RT (2017) Herbivore regulation of plant abundance in aquatic ecosystems. Biol Rev 92:1128-1141

Wood KA, Ponting J, D’Costa N, Newth JL, Rose PE, Glazov P, Rees EC (2017) Understanding intrinsic and extrinsic drivers of aggressive behavior in waterbird assemblages: a meta-analysis. Anim Behav 126:209-216

Wood KA, Stillman RA, Clarke RT, Daunt F, O'Hare MT (2012) The impact of waterfowl herbivory on plant standing crop: a meta-analysis. Hydrobiologia 686:157-167 
1 Table 1 Geographic coordinates of the southernmost, northernmost, westernmost and easternmost study lake in each of the six study regions in Finland and

2 Sweden. Number of lakes in which Equisetum, Eurasian Wigeon and Whooper Swan occurred (value before slash) or did not occur (value after slash) in the

3 first (1990-1991) and second study period (2013-2014 for Equisetum; 2016 for Eurasian Wigeon and Whooper Swan) is also given for each region. Region

4 names and numbers correspond to those in Fig. 1 of Elmberg et al. 1993

5

\begin{tabular}{|c|c|c|c|c|c|c|c|}
\hline & & $\begin{array}{l}\text { Lappi (1), } \\
\text { Finland }\end{array}$ & $\begin{array}{l}\text { Västerbotten (2), } \\
\text { Sweden }\end{array}$ & $\begin{array}{l}\text { Häme (3), } \\
\text { Finland }\end{array}$ & $\begin{array}{l}\text { Karjala (4), } \\
\text { Finland }\end{array}$ & $\begin{array}{l}\text { Södermanland (5), } \\
\text { Sweden }\end{array}$ & $\begin{array}{l}\text { Scania (6), } \\
\text { Sweden }\end{array}$ \\
\hline \multirow{4}{*}{$\begin{array}{l}\text { Coordinates of } \\
\text { furthermost lakes }\end{array}$} & South & $66^{\circ} 49^{\prime} \mathrm{N}$ & $63^{\circ} 45^{\prime} \mathrm{N}$ & $61^{\circ} 10^{\prime} \mathrm{N}$ & $61^{\circ} 32^{\prime} \mathrm{N}$ & $58^{\circ} 57^{\prime} \mathrm{N}$ & $55^{\circ} 53^{\prime} \mathrm{N}$ \\
\hline & North & $67^{\circ} 03^{\prime} \mathrm{N}$ & $64^{\circ} 02^{\prime} \mathrm{N}$ & $61^{\circ} 14^{\prime} \mathrm{N}$ & $61^{\circ} 39^{\prime} \mathrm{N}$ & $59^{\circ} 20^{\prime} \mathrm{N}$ & $56^{\circ} 19^{\prime} \mathrm{N}$ \\
\hline & West & $25^{\circ} 05^{\prime} \mathrm{E}$ & $19^{\circ} 36^{\prime} \mathrm{E}$ & $25^{\circ} 02^{\prime} \mathrm{E}$ & $29^{\circ} 33^{\prime} \mathrm{E}$ & $16^{\circ} 22^{\prime} \mathrm{E}$ & $14^{\circ} 12^{\prime} \mathrm{E}$ \\
\hline & East & $25^{\circ} 36^{\prime} \mathrm{E}$ & $20^{\circ} 22^{\prime} \mathrm{E}$ & $25^{\circ} 09^{\prime} \mathrm{E}$ & $29^{\circ} 47^{\prime} \mathrm{E}$ & $16^{\circ} 45^{\prime} \mathrm{E}$ & $14^{\circ} 24^{\prime} \mathrm{E}$ \\
\hline \multirow[t]{2}{*}{ Equisetum } & 1990-1991 & $6 / 2$ & $5 / 5$ & $5 / 5$ & $5 / 5$ & $2 / 8$ & $4 / 6$ \\
\hline & 2013-2014 & $7 / 1$ & $3 / 7$ & $0 / 10$ & $2 / 8$ & $0 / 10$ & $0 / 10$ \\
\hline
\end{tabular}




\begin{tabular}{|l|l|l|l|l|l|l|l|}
\hline Eurasian Wigeon & $1990-1991$ & $4 / 5$ & $4 / 6$ & $2 / 8$ & $6 / 4$ & $1 / 9$ & $1 / 9$ \\
\cline { 2 - 8 } & 2016 & $1 / 8$ & $1 / 9$ & $0 / 10$ & $7 / 3$ & $0 / 10$ & $0 / 10$ \\
\hline Whooper Swan & $1990-1991$ & $2 / 7$ & $0 / 10$ & $1 / 9$ & $0 / 10$ & $0 / 10$ & $0 / 10$ \\
\cline { 2 - 8 } & 2016 & $4 / 5$ & $3 / 7$ & $3 / 7$ & $4 / 6$ & $2 / 8$ & $0 / 10$ \\
\hline
\end{tabular}


1 Table 2 Total length (m) of Equisetum-dominated shoreline and the proportion (\%) of Equisetum-

2 dominated shoreline of total shoreline in 1990-1991 in lakes colonized and not colonized by Whooper

3 Swan after 1990-1991. Lakes $(n=47)$ from five study regions in which Whooper Swan was observed

4 either in 1990-1991 or 2016 are included (lakes that were occupied by Whooper Swan already in

$5 \quad 1990-1991$ were excluded)

Lakes colonized by Lakes not colonized by $U \quad p$

Whooper Swan Whooper Swan

$\begin{array}{lll}\text { Equisetum-dominated } & \text { Mean } 947 & 945\end{array}$

shoreline (m)

$\begin{array}{lllll}\text { Median } & 474 & 0 & 107.5 & 0.003 \\ \text { Range } & 0-3493 & 0-1600 & & \\ n & 13 & 34 & \end{array}$

Proportion of Equisetum- $\quad$ Mean $\quad 38.1 \quad 11.2$

dominated shoreline $(\%)$

$\begin{array}{lllll}\text { Median } & 16.0 & 0 & 118.0 & 0.008 \\ \text { Range } & 0-100 & 0-100 & & \\ n & 13 & 34 & \end{array}$

6

$7 \quad U$, Mann-Whitney $U$-test statistics for the comparison of medians between lakes colonized and lakes

8 not colonized by the Whooper Swan; $n$, sample size 
1 Table 3 Absolute (m) and proportional (\%) change of Equisetum-dominated shoreline from 1990-

21991 to 2013-2014 in lakes colonized and not colonized by Whooper Swan after 1990-1991. Only

3 lakes $(n=27)$ in which Equisetum occurred either in 1990-1991 or 2013-2014 are included (lakes

4 that were occupied by Whooper Swan already in 1990-1991 were excluded)

$\begin{array}{lll}\text { Lakes colonized by } & \text { Lakes not colonized by } & U\end{array}$

Absolute change of $\quad$ Mean $\quad-858 \quad-385$

Equisetum-dominated

shoreline (m)

$\begin{array}{lllll}\text { Median } & -716 & -286 & 120.0 & 0.079 \\ \text { Range } & -1935-(+210) & -1600-(+324) & & \\ n & 10 & 17 & \end{array}$

Proportional change of $\quad$ Mean $\quad-69.4 \quad-68.0$

Equisetum-dominated

shoreline $(\%)$

$\begin{array}{lllll}\text { Median } & -86.7 & -100 & 63.0 & 0.215 \\ \text { Range } & -100-(+43.8) & -100-(+100) & & \\ n & 10 & 17 & \end{array}$

5

$U$, Mann-Whitney $U$-test statistics for the comparison of medians between lakes colonized and lakes not colonized by the Whooper Swan; $n$, sample size 
1 Table 4 Absolute (number of pairs) and proportional (\%) change of Eurasian Wigeon pair numbers

2 from 1990-1991 to 2016 in lakes colonized and not colonized by Whooper Swan after 1990-1991.

3 Only lakes $(n=18)$ in which Eurasian Wigeon occurred either in 1990-1991 or in 2013-2014 are

4 included (lakes that were occupied by Whooper Swan already in 1990-1991 were excluded)

Lakes colonized by Lakes not colonized by $U \quad p$

Whooper Swan Whooper Swan

Absolute change of $\quad$ Mean $\quad-0.5 \quad-0.5$

Eurasian Wigeon pair

number

$\begin{array}{lllll}\text { Median } & -1.0 & -0.5 & 47.0 & 0.436 \\ \text { Range } & -2.5-(+5.0) & -3.0-(+1.5) & & \\ n & 11 & 7\end{array}$

Proportional change of $\quad$ Mean $\quad-49.3 \quad-37.7$

Eurasian Wigeon pair

number $(\%)$

$\begin{array}{lllll}\text { Median } & -66.7 & -100 & 37.5 & 0.923 \\ \text { Range } & -100-(+100) & -100-(+100) & & \\ n & 11 & 7 & \end{array}$

5

$6 U$, Mann-Whitney $U$-test statistics for the comparison of medians between lakes colonized and lakes

7 not colonized by the Whooper Swan; $n$, sample size 
1 Table 5 Absolute (number of pairs) and proportional (\%) change of Eurasian Wigeon pair numbers

2 from 1990-1991 to 2016 in lakes that had either totally lost Equisetum since 1990-1991 and in lakes

3 in which there was still some Equisetum left in 2013-2014. Only lakes $(n=15)$ in which both

4 Eurasian Wigeon and Equisetum were observed either in 1990-1991 or in 2013-2014/2016 are

5 included

Lakes with

Equisetum totally

lost
Lakes with Equisetum $\quad U \quad p$

still left

Absolute change of

Mean

$-1.3$

$-0.6$

Eurasian Wigeon pair

number

$\begin{array}{lll}\text { Median } & -1.0 & -1.0 \\ \text { Range } & -2.5-(-0.5) & -3.5-(-5.0) \\ n & 6 & 9\end{array}$

$\begin{array}{llll}\text { Proportional change of } & \text { Mean } & -74.2 & -49.6\end{array}$

Eurasian Wigeon pair

number $(\%)$

$\begin{array}{lllll}\text { Median } & -75.0 & -100 & 28.5 & 0.848 \\ \text { Range } & -100-(-45.5) & -100-(+100) & & \\ n & 6 & 9 & \end{array}$


$1 U$, Mann-Whitney $U$-test statistics for the comparison of medians between lakes from which

2 Equisetum disappeared and lakes in which there was still some Equisetum left in 2013-2014; n,

3 sample size 